\title{
Mobile Usage and its Impact on Interpersonal Relationships and Work Efficiency
}

\author{
Garima Gupta ${ }^{1 *}$ \\ ${ }^{1}$ School of Open Learning, University of Delhi India \\ *Corresponding Author \\ Garima Gupta
}

\section{Article History}

Received: 09.02.2021

Accepted: 20.02.2021

Published: 28 .02.2021

\begin{abstract}
In the contemporary world one can hardly find someone without a smartphone; where his/her fingers would be busy texting online with a person(s) on the other end. Social Networking Sites (SNS) are clearly becoming an effective, efficient, reliable and chosen form of communication. At present, the usage of SNSs has increased drastically which has an extensive influence on people in numerous ways, particularly on their interpersonal relationships. Smartphones have become increasingly popular for personal, professional and official use. This research investigates the impact of SNS on the interpersonal relationships of officers/employees/friends/neighbours and impact on work efficiency due to their increasing usage of smart phones. Smartphone usage at workplace, whether it for assistance or an interference to work and its implications on performance of employees.
\end{abstract}

Keywords: Mobile Usage, Interpersonal Relationships, Work Efficiency.

\section{INTRODUCTION}

The smartphone technology which came into existence nearly two decades ago has caused drastic changes in the field of communication. Smartphones have been developing at a very rapid pace and are increasingly integrating into people's lives. The impacts of using smartphones at workplace may be positive or negative which may influence work productivity of any organization [1].

Social networking sites have gained tremendous popularity among people all over the globe. The use of SNSs has become a popular and an integral part of everyday communication of every human being. New developments in the technological world have made the internet an innovative way for individuals and families to communicate and stay in touch with each other. People use social network sites such as Facebook, Twitter, Snapchat and WhatsApp to create and sustain relationships with others. SNSs also help people to develop their friendship and even find new friends. People use SNS to communicate with family, friends, and even strangers. Today people are using the internet mostly to interact on social media, they chat, message, share photos, videos and stay in touch with friends and relatives worldwide. SNSs allow users to share their ideas, pictures, posts, activities, events, and interests with people in their network and also publicly [2].

\section{LiTERATURE REVIEW}

Communication is a process in which participants create and share information with each other in order to reach a mutual understanding. Due to technological advances in the era and increased use of the Internet in recent years have led to a communication revolution. This communication revolution has changed the way people communicate with each other [3].

Smartphones have helped employers as well as employees to improve relationships with each other [4]. Smartphone enables employees to organise their work, manage their work. It also gives them more opportunity to be creative and efficient in scheduling their work and meetings. At the same time, it also gives an opportunity to

Copyright (C) 2021 The Author(s): This is an open-access article distributed under the terms of the Creative Commons Attribution 4.0 International License (CC BY-NC 4.0) which permits unrestricted use, distribution, and reproduction in any medium for noncommercial use provided the original author and source are credited. 
individualise work and provide physical freedom of movement in work [1]. Using Smartphones at workplace can be valuable as they strengthen the relationship between superiors and subordinates. It also improves knowledge-sharing among them. Moreover, these factors increase employee job satisfaction, which leads to better efficiency and more productivity in the workplace [5].

Smartphones in the workplaces also have some negative impacts like lowering productivity, disconnecting people from reality and increasing stress. It may distract employees to engage in non-work purposes and may engage them in unproductive and unethical activities such as online shopping, news, music, chatting and games while at work. Smartphone usage distracts employees from information at meetings, and also annoys others [6].

Winston Churchill said that "A pessimist sees the difficulty in every opportunity; an optimist sees the opportunity in every difficulty". This quote suggests looking at the positive sides of smartphones that can potentially benefit companies. Smartphone is a high potential device that connects people together through the medium of internet. CEOs or Managers should take this as an opportunity to turn their employees' Smartphones into engagement tools [7].

With the integration of Smartphone and social network applications, people can share their information and knowledge easily. Internal social networks have experienced a rise in popularity, offering employees and managers a knowledge-share opportunity and a virtual collaboration platform. One of the most effective, reliable and popular tools for knowledge sharing is Cloud computing. The combination of Smartphone and the Cloud computing has a potential to expand knowledge faster and better because Smartphone users can connect and access information anytime and anywhere, which open up many opportunities for them to learn more. If corporate leaders manage it properly, it will be a good chance for their business to grow potentially. Business leaders should use the Smartphone advantage by integrating Smartphone usage with workflow in order to increase the level of work efficiency which will increase the productivity and businesses will flourish.

Social media has shown significant growth as the most preferred medium of communication. The benefits offered by this media, is instant contact anywhere in the world with easy accessibility. Messages can be shared and spread farther and faster than ever. As communication become faster the world seems to shrink.

One of the biggest positive changes due to social media networks is in the way that we interact, the number of people that we can interact with. With the advent of SNS, people are now able to interact with thousands of people all over the world - this is the reason why there are people who have thousands of Facebook friends or tens of thousands of Instagram followers. Without SNS, this would be never be possible. SNS allow us the opportunity to share opinions with a wider audience. Before social media, we were extremely limited in our means to interact with others to the people that we knew in-person [8].

Social media has also changed the way that we interact. This has led to loss of or social skills. Some people are completely incapable of carrying on a normal conversation or interacting with people in person because of the dependency of social media. This has also led to avoidance of face-to-face communication (Subramanian, 2017). The mobile phone has created a social situation whereby people are getting used to avoidance of person-to-person communication by switching over to mobile. The present day lifestyle and lack of time have made the usage of mobile phones more useful for social contact [9].

Loss of privacy is also an emerging concern. Since massive information is spread through social media at a click, there is no room for privacy - everybody knows everything about the other person which is a dangerous situation which can lead to herd mentality and the individual may lose his discretion [10].

\section{RESEARCH OBJECTIVES}

The objectives of the research are to:

i. Study the relationship between the age of the respondents and the most preferred SNS used by them.

ii. Study the relationship between the educational qualifications of the respondents and the importance of SNS in their academic work.

iii. Study the relationship between the age of the respondents and their purpose of choosing SNS for maintaining interpersonal relationships.

iv. Study the relationship between the type of mobile connection that respondents possess and its effects on interpersonal relationships among colleagues.

v. Study the relationship between the time spent by males and females on SNS per day and their purpose of using SNS. 


\section{Data And its Sources And Methodology}

Individuals were the unit of analysis. Convenience sampling has been used as the sampling method and the data was collected from the region of Delhi NCR.

Table-1: Gender

\begin{tabular}{|l|l|l|l|}
\hline \multicolumn{2}{|c|}{} & Frequency & Percent (\%) \\
\hline \multirow{3}{*}{ Valid } & $\mathrm{F}$ & 23 & 41.8 \\
\cline { 2 - 4 } & $\mathrm{M}$ & 32 & 58.2 \\
\cline { 2 - 4 } & Total & 55 & 100.0 \\
\hline
\end{tabular}

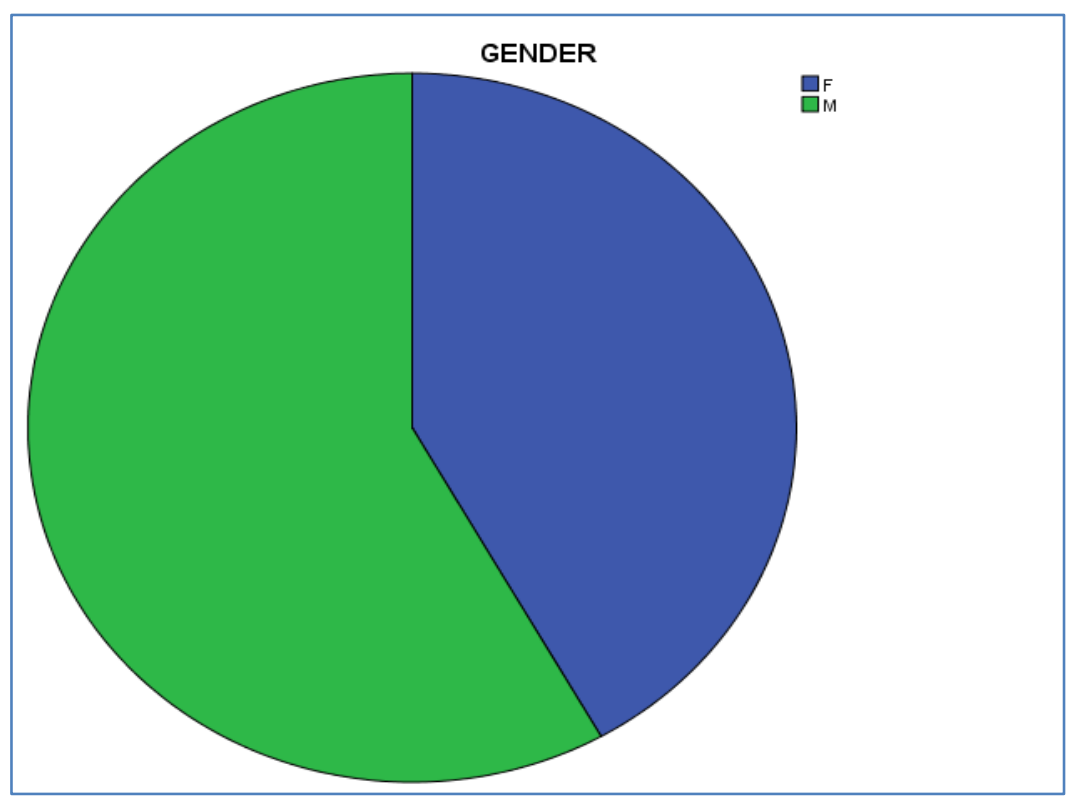

Table-2: Descriptive Statistics of Age

\begin{tabular}{|r|r|r|r|r|r|}
\hline & N & Minimum & Maximum & Mean & Std. Deviation \\
\hline AGE & 55 & 20 & 57 & 31.07 & 9.518 \\
\hline
\end{tabular}

The sample size for this research was 55 . Out of these $41.8 \%$ were females and $58.2 \%$ males. On the other hand, responses were collected from respondents aging between 20-57 years of age. Google Forms.

For the purpose of this research a structured questionnaire was designed and responses were collected using

\section{Data AnAlysis And InTERPRETATIONS}

$\mathrm{H}_{0}$ : There is no significant relationship between age of the respondent and the most preferred SNS used by them

Table-3: Case Processing Summary

\begin{tabular}{|c|l|c|c|c|c|c|c|}
\hline \multirow{2}{*}{} & \multirow{2}{*}{ MOST PREFERRED SNS } & \multicolumn{6}{|c|}{ Cases } \\
\cline { 3 - 8 } & & \multicolumn{2}{|c|}{ Valid } & \multicolumn{2}{|c|}{ Missing } & \multicolumn{2}{|c|}{ Total } \\
\cline { 3 - 8 } & & $\mathrm{N}$ & Percent & $\mathrm{N}$ & Percent & $\mathrm{N}$ & Percent \\
\hline \multirow{2}{*}{ AGE } & ANY OTHER & 19 & $100.0 \%$ & 0 & $.0 \%$ & 19 & $100.0 \%$ \\
\cline { 2 - 8 } & FACEBOOK & 10 & $100.0 \%$ & 0 & $.0 \%$ & 10 & $100.0 \%$ \\
\cline { 2 - 8 } & WHATSAPP & 26 & $100.0 \%$ & 0 & $.0 \%$ & 26 & $100.0 \%$ \\
\hline
\end{tabular}


Table-4: Descriptives

\begin{tabular}{|c|c|c|c|c|c|}
\hline \multirow{2}{*}{ AGE } & \multicolumn{3}{|c|}{ MOST PREFERRED SNS } & \multirow{2}{*}{$\begin{array}{r}\text { Statistic } \\
23.37 \\
\end{array}$} & \multirow{2}{*}{$\begin{array}{r}\text { Std. Error } \\
.568\end{array}$} \\
\hline & \multirow[t]{10}{*}{ ANY OTHER } & \multicolumn{2}{|l|}{ Mean } & & \\
\hline & & \multirow[t]{2}{*}{ 95\% Confidence Interval for Mean } & Lower Bound & & \\
\hline & & & Upper Bound & 24.56 & \\
\hline & & \multicolumn{2}{|l|}{ Median } & 23.00 & \\
\hline & & \multicolumn{2}{|l|}{ Variance } & 6.135 & \\
\hline & & \multicolumn{2}{|l|}{ Std. Deviation } & 2.477 & \\
\hline & & \multicolumn{2}{|l|}{ Minimum } & 20 & \\
\hline & & \multicolumn{2}{|l|}{ Maximum } & 30 & \\
\hline & & \multicolumn{2}{|l|}{ Skewness } & .899 & .524 \\
\hline & & \multirow{2}{*}{\multicolumn{2}{|c|}{$\begin{array}{l}\text { Kurtosis } \\
\text { Mean }\end{array}$}} & 1.398 & 1.014 \\
\hline & \multirow[t]{10}{*}{ FACEBOOK } & Mean & & 31.60 & 2.130 \\
\hline & & \multirow[t]{2}{*}{ 95\% Confidence Interval for Mean } & Lower Bound & 26.78 & \\
\hline & & & Upper Bound & 36.42 & \\
\hline & & \multicolumn{2}{|l|}{ Median } & 31.00 & \\
\hline & & \multicolumn{2}{|l|}{ Variance } & 45.378 & \\
\hline & & \multirow{2}{*}{\multicolumn{2}{|c|}{$\begin{array}{l}\text { Std. Deviation } \\
\text { Minimum }\end{array}$}} & 6.736 & \\
\hline & & & & 24 & \\
\hline & & \multicolumn{2}{|l|}{ Maximum } & 45 & \\
\hline & & \multicolumn{2}{|l|}{ Skewness } & .903 & 687 \\
\hline & & \multicolumn{2}{|l|}{ Kurtosis } & .383 & 1.334 \\
\hline & \multirow[t]{10}{*}{ WHATSAPP } & \multicolumn{2}{|l|}{ Mean } & 36.50 & 1.952 \\
\hline & & \multirow[t]{2}{*}{ 95\% Confidence Interval for Mean } & Lower Bound & 32.48 & \\
\hline & & & Upper Bound & 40.52 & \\
\hline & & \multicolumn{2}{|l|}{ Median } & 34.00 & \\
\hline & & \multicolumn{2}{|l|}{ Variance } & 99.060 & \\
\hline & & \multicolumn{2}{|l|}{ Std. Deviation } & 9.953 & \\
\hline & & \multicolumn{2}{|l|}{ Minimum } & 22 & \\
\hline & & \multirow{2}{*}{\multicolumn{2}{|c|}{$\begin{array}{l}\text { Maximum } \\
\text { Skewness }\end{array}$}} & 57 & \\
\hline & & & & .517 & .456 \\
\hline & & Kurtosis & & -.365 & .887 \\
\hline
\end{tabular}

The non-response rate is $0 \%$. Respondents whose most preferred SNS is Facebook are from the age bracket of 24-45 years having a mean age of 31.6 years. The deviation from the mean age is of 6.736 years. The skewness and kurtosis of the same are 0.903 and 0.383 years respectively.

On the other hand, respondents whose most preferred SNS is WhatsApp are from the age bracket of 22-57 years having a mean age of 36.5 years. The deviation from the mean age is of 9.953 years. The skewness and kurtosis of the same are 0.517 and -0.365 years respectively.

Similarly, respondents whose most preferred SNS is any other than Facebook, WhatsApp and Twitter like Instagram, Snapchat, YouTube, etc. are from the age bracket of 20-30 years having a mean age of 23.37 years. The deviation from the mean age is of 2.477 years. The skewness and kurtosis of the same are 0.899 and 1.398 years respectively.

Table-5: ANOVA

\begin{tabular}{|l|r|r|r|r|r|}
\hline & \multicolumn{1}{|c|}{ Sum of Squares } & \multicolumn{1}{|c|}{ df } & Mean Square & \multicolumn{1}{c|}{ F } & \multicolumn{1}{c|}{ Sig. } \\
\hline Between Groups & 1896.388 & 2 & 948.194 & 16.461 & .000 \\
\hline Within Groups & 2995.321 & 52 & 57.602 & & \\
\hline Total & 4891.709 & 54 & & & \\
\hline
\end{tabular}

We carried out one way ANOVA to find the significant relationship between the age of respondents and the most preferred SNS used by them.

Since the significance value i.e., 0.000 is less than the level of significance of $5 \%(0.05)$ we could find sufficient evidences to reject the null hypothesis and hence conclude that the difference between the two variables is significant at $5 \%$. 
This implies that there is a significant relationship between the age of respondents and the most preferred SNS used by them.

$\mathrm{H}_{0}$ : There is no significant relationship between the educational qualifications of the respondents and the importance of SNS in their academic work

Table-6: Case Processing Summary

\begin{tabular}{|c|c|c|c|c|c|c|}
\hline & \multicolumn{6}{|c|}{ Cases } \\
\hline & \multicolumn{2}{|c|}{ Valid } & \multicolumn{2}{|c|}{ Missing } & \multicolumn{2}{|c|}{ Total } \\
\hline & $\mathbf{N}$ & Percent & $\mathbf{N}$ & Percent & $\mathbf{N}$ & Percent \\
\hline $\begin{array}{l}\text { EDUCATIONAL QUALIFICATION * } \\
\text { IMPORTANCE IN ACADEMIC WORK }\end{array}$ & 55 & $100.0 \%$ & 0 & $.0 \%$ & 55 & $100.0 \%$ \\
\hline
\end{tabular}

Table-7: Educational qualification * importance in academic work Crosstabulation

\begin{tabular}{|c|c|c|c|c|c|}
\hline & & & \multicolumn{2}{|c|}{$\begin{array}{l}\text { IMPORTANCE IN } \\
\text { ACADEMIC WORK }\end{array}$} & \multirow[t]{2}{*}{ Total } \\
\hline & & & IMPORTANT & ITS USEFUL & \\
\hline \multirow{4}{*}{$\begin{array}{l}\text { EDUCATIONAL } \\
\text { QUALIFICATION }\end{array}$} & \multirow[t]{2}{*}{ GRADUATE } & Count & 20 & 19 & 39 \\
\hline & & $\%$ of Total & $36.4 \%$ & $34.5 \%$ & $70.9 \%$ \\
\hline & \multirow{2}{*}{$\begin{array}{l}\text { POST } \\
\text { GRADUATE }\end{array}$} & Count & 9 & 7 & 16 \\
\hline & & $\%$ of Total & $16.4 \%$ & $12.7 \%$ & $29.1 \%$ \\
\hline \multirow{2}{*}{\multicolumn{2}{|c|}{ Total }} & Count & 29 & 26 & 55 \\
\hline & & $\%$ of Total & $52.7 \%$ & $47.3 \%$ & $100.0 \%$ \\
\hline
\end{tabular}

The non-response rate is $0 \%$. Out of $70.9 \%$ graduates, $36.4 \%$ feel that SNS plays an important role in their academic work while $34.5 \%$ find SNS useful for their academic purposes. On the other hand, out of $29.1 \%$ post graduates, $16.4 \%$ find SNS is important for their academic work while $12.7 \%$ find it useful for the same.

Table-8: Chi-Square Tests

\begin{tabular}{|l|l|l|l|}
\hline & Value & df & Asymp. Sig. (2-sided) \\
\hline Pearson Chi-Square & $.112^{\mathrm{a}}$ & 1 & .737 \\
\hline Continuity Correction $^{\mathbf{b}}$ & .001 & 1 & .970 \\
\hline Likelihood Ratio & .113 & 1 & .737 \\
\hline Fisher's Exact Test & & & \\
\hline Linear-by-Linear Association & .110 & 1 & .740 \\
\hline N of Valid Cases & 55 & & \\
\hline
\end{tabular}

a. 0 cells $(.0 \%)$ have expected count less than 5. The minimum expected count is 7.56.

b. Computed only for a $2 \times 2$ table

We carried out Chi-square test to test the significance of association between the educational qualifications of the respondents and the importance of SNS on their academic work.

Since the significance value i.e., 0.737 is greater than the level of significance of $5 \%(0.05)$ we could not find sufficient evidences to reject the null hypothesis and hence conclude that association between the two attributes is insignificant at $5 \%$.

This implies that there is no significant relationship between the educational qualifications of the respondents and the importance of SNS on their academic work.

$\mathrm{H}_{0}$ : There is no significant relationship between the age of the respondents and their purpose of choosing SNS for maintaining interpersonal relationships.

Table-9: Case Processing Summary

\begin{tabular}{|c|c|c|c|c|c|c|c|}
\hline \multirow{3}{*}{\multicolumn{2}{|c|}{$\begin{array}{l}\text { PURPOSE OF USING SNS FOR INTERPERSONAL } \\
\text { RELATIONSHIPS }\end{array}$}} & \multicolumn{6}{|c|}{ Cases } \\
\hline & & \multicolumn{2}{|c|}{ Valid } & \multicolumn{2}{|c|}{ Missing } & \multicolumn{2}{|c|}{ Total } \\
\hline & & $\mathbf{N}$ & Percent & $\mathbf{N}$ & Percent & $\mathbf{N}$ & Percent \\
\hline \multirow{3}{*}{ AGE } & ALWAYS WANTED TO KEEP IN TOUCH & 11 & $100.0 \%$ & 0 & $.0 \%$ & 11 & $100.0 \%$ \\
\hline & BETTER COMMUNICATION & 17 & $100.0 \%$ & 0 & $.0 \%$ & 17 & $100.0 \%$ \\
\hline & MORE INTERACTION & 27 & $100.0 \%$ & 0 & $.0 \%$ & 27 & $100.0 \%$ \\
\hline
\end{tabular}


Table-10: Descriptives

\begin{tabular}{|c|c|c|c|c|c|}
\hline \multirow{3}{*}{$\begin{array}{l} \\
\text { AG } \\
\text { E }\end{array}$} & \multicolumn{3}{|c|}{$\begin{array}{l}\text { PURPOSE OF USING SNS FOR INTERPERSONAL } \\
\text { RELATIONSHIPS }\end{array}$} & \multirow{2}{*}{$\begin{array}{r}\text { Statistic } \\
35.00 \\
\end{array}$} & \multirow{2}{*}{$\begin{array}{r}\text { Std. Error } \\
4.200\end{array}$} \\
\hline & \multirow{10}{*}{$\begin{array}{l}\text { ALWAYS } \\
\text { WANTED TO } \\
\text { KEEP IN TOUCH }\end{array}$} & \multicolumn{2}{|l|}{ Mean } & & \\
\hline & & \multirow{2}{*}{$\begin{array}{l}95 \% \text { Confidence Interval } \\
\text { for Mean }\end{array}$} & Lower Bound & 25.64 & \\
\hline & & & Upper Bound & 44.36 & \\
\hline & & \multicolumn{2}{|l|}{ Median } & 32.00 & \\
\hline & & \multicolumn{2}{|l|}{ Variance } & 194.000 & \\
\hline & & \multicolumn{2}{|l|}{ Std. Deviation } & 13.928 & \\
\hline & & \multicolumn{2}{|l|}{ Minimum } & 21 & \\
\hline & & \multicolumn{2}{|l|}{ Maximum } & 57 & \\
\hline & & \multicolumn{2}{|l|}{ Skewness } & .864 & .661 \\
\hline & & \multicolumn{2}{|l|}{ Kurtosis } & -.985 & 1.279 \\
\hline & \multirow{10}{*}{$\begin{array}{l}\text { BETTER } \\
\text { COMMUNICATI } \\
\text { ON }\end{array}$} & \multicolumn{2}{|l|}{ Mean } & 37.88 & 1.649 \\
\hline & & \multirow{2}{*}{$\begin{array}{l}95 \% \text { Confidence Interval } \\
\text { for Mean }\end{array}$} & Lower Bound & 34.39 & \\
\hline & & & Upper Bound & 41.38 & \\
\hline & & \multicolumn{2}{|l|}{ Median } & 40.00 & \\
\hline & & \multicolumn{2}{|l|}{ Variance } & 46.235 & \\
\hline & & \multicolumn{2}{|l|}{ Std. Deviation } & 6.800 & \\
\hline & & \multicolumn{2}{|l|}{ Minimum } & 20 & \\
\hline & & \multicolumn{2}{|l|}{ Maximum } & 45 & \\
\hline & & \multicolumn{2}{|l|}{ Skewness } & -1.110 & .550 \\
\hline & & \multicolumn{2}{|l|}{ Kurtosis } & 1.373 & 1.063 \\
\hline & \multirow{10}{*}{$\begin{array}{l}\text { MORE } \\
\text { INTERACTION }\end{array}$} & \multicolumn{2}{|l|}{ Mean } & 25.19 & .673 \\
\hline & & \multirow{2}{*}{$\begin{array}{l}95 \% \text { Confidence Interval } \\
\text { for Mean }\end{array}$} & Lower Bound & 23.80 & \\
\hline & & & Upper Bound & 26.57 & \\
\hline & & \multicolumn{2}{|l|}{ Median } & 24.00 & \\
\hline & & \multicolumn{2}{|l|}{ Variance } & 12.234 & \\
\hline & & \multicolumn{2}{|l|}{ Std. Deviation } & 3.498 & \\
\hline & & \multicolumn{2}{|l|}{ Minimum } & 20 & \\
\hline & & Maximum & & 34 & \\
\hline & & Skewness & & .788 & .448 \\
\hline & & Kurtosis & & .067 & .872 \\
\hline
\end{tabular}

The non-response rate is $0 \%$. Respondents whose purpose of using SNS is to always wanting to keep in touch for maintaining their interpersonal relationships belong to the age bracket of 21-57 years having a mean age of 35 years. The deviation from the mean age is of 13.928 years. The skewness and kurtosis of the same are 0.864 and -0.985 years.

On the other hand, respondents whose purpose of using SNS is to have better communication for maintaining their interpersonal relationships belong to the age bracket of $20-45$ years having a mean age of 37.88 years. The deviation from the mean age is of 6.8 years. The skewness and kurtosis of the same are -1.110 and 1.373 years.

Similarly, respondents whose purpose of using SNS is to have more interaction for maintaining their interpersonal relationships belong to the age bracket of 20-34 years having a mean age of 25.19 years. The deviation from the mean age is of 3.398 years. The skewness and kurtosis of the same are 0.788 and 0.067 years.

Table-11: ANOVA

\begin{tabular}{|l|r|r|r|r|c|}
\hline & Sum of Squares & df & Mean Square & F & Sig. \\
\hline Between Groups & 1893.870 & 2 & 946.935 & 16.425 & .000 \\
\hline Within Groups & 2997.839 & 52 & 57.651 & & \\
\hline Total & 4891.709 & 54 & & & \\
\hline
\end{tabular}

We carried out one way ANOVA to find the significant relationship between the age of respondents and their purpose of choosing SNS for maintaining interpersonal relationships.

Since the significance value i.e., 0.000 is less than the level of significance of $5 \%(0.05)$ we could find sufficient evidences to reject the null hypothesis and hence conclude that the difference between the two attributes is significant at $5 \%$. 
This implies that there is a significant relationship between the age of respondents and their purpose of choosing SNS for maintaining interpersonal relationships.

$\mathrm{H}_{0}$ : There is no significant relationship between the type of mobile connection that respondents possess and its effects on interpersonal relationships among colleagues.

Table-12: Case Processing Summary

\begin{tabular}{|c|c|c|c|c|c|c|}
\hline & \multicolumn{6}{|c|}{ Cases } \\
\hline & \multicolumn{2}{|c|}{ Valid } & \multicolumn{2}{|c|}{ Missing } & \multicolumn{2}{|c|}{ Total } \\
\hline & $\mathbf{N}$ & Percent & $\mathbf{N}$ & Percent & $\mathbf{N}$ & Percent \\
\hline $\begin{array}{l}\text { TYPE OF CONNECTION * } \\
\text { EFFECTS ON INTERPERSONAL } \\
\text { RELATIONSHIPS AMONG } \\
\text { COLLEAGUES }\end{array}$ & 55 & $100.0 \%$ & 0 & $.0 \%$ & 55 & $100.0 \%$ \\
\hline
\end{tabular}

Table-13: Type of connection * effects on interpersonal relationships among colleagues Crosstabulation

\begin{tabular}{|c|c|c|c|c|c|c|}
\hline & \multicolumn{3}{|c|}{$\begin{array}{l}\text { Effects on interpersonal relationships among } \\
\text { colleagues }\end{array}$} & \multirow[t]{2}{*}{ Total } \\
\hline & & & $\begin{array}{l}\text { STRONGLY } \\
\text { AGREE }\end{array}$ & AGREE & $\begin{array}{l}\text { DISAGRE } \\
\text { E }\end{array}$ & \\
\hline \multirow{4}{*}{$\begin{array}{l}\text { TYPE OF } \\
\text { CONNECTIO } \\
\mathbf{N}\end{array}$} & \multirow[t]{2}{*}{ PREPAID } & Count & 5 & 26 & 6 & 37 \\
\hline & & $\%$ of Total & $9.1 \%$ & $47.3 \%$ & $10.9 \%$ & $67.3 \%$ \\
\hline & \multirow{2}{*}{$\begin{array}{l}\text { POST } \\
\text { PAID }\end{array}$} & Count & 5 & 8 & 5 & 18 \\
\hline & & $\%$ of Total & $9.1 \%$ & $14.5 \%$ & $9.1 \%$ & $32.7 \%$ \\
\hline \multirow{2}{*}{\multicolumn{2}{|c|}{ Total }} & Count & 10 & 34 & 11 & 55 \\
\hline & & $\%$ of Total & $18.2 \%$ & $61.8 \%$ & $20.0 \%$ & $100.0 \%$ \\
\hline
\end{tabular}

The non-response rate is $0 \%$. Out of $32.7 \%$ of respondents who use post-paid mobile connection, $9.1 \%$ strongly agree, $14.5 \%$ agree and $9.1 \%$ disagree that mobile phones have affected their interpersonal relations among colleagues. On the other hand, out of $67.3 \%$ of respondents who possess prepaid mobile connection, $9.1 \%$ strongly agree that mobile phones have affected their interpersonal relations among colleagues, while, $47.3 \%$ agree and $10.9 \%$ disagree with this statement.

Table-14: Chi-Square Tests

\begin{tabular}{|l|r|r|r|}
\hline & Value & df & Asymp. Sig. (2-sided) \\
\hline Pearson Chi-Square & $3.471^{\mathrm{a}}$ & 2 & .176 \\
\hline Likelihood Ratio & 3.424 & 2 & .181 \\
\hline Linear-by-Linear Association & .023 & 1 & .880 \\
\hline N of Valid Cases & 55 & & \\
\hline a. 2 cells (33.3\%) have expected count less than 5. The minimum expected count is 3.27. \\
\hline
\end{tabular}

We carried out Chi-square test to test the significance of association between the type of mobile connection respondents possess and its effects on interpersonal relationships among colleagues.

Since the significance value i.e., 0.176 is greater than the level of significance of $5 \%(0.05)$ we could not find sufficient evidences to reject the null hypothesis and hence conclude that association between the two attributes is insignificant at $5 \%$.

This implies that there is no significant relationship between the type of mobile connection respondents possess and its effects on interpersonal relationships among colleagues.

$\mathrm{H}_{0}$ : There is no significant relationship between the time spent by males and females on SNS per day and their purpose of using SNS 


\begin{tabular}{|c|c|c|c|c|c|c|c|}
\hline \multicolumn{8}{|c|}{ Table-15 } \\
\hline & & & & \multicolumn{4}{|c|}{ Purpose of using sns } \\
\hline & & & & $\begin{array}{l}\text { Just for } \\
\text { fun }\end{array}$ & $\begin{array}{l}\text { Keeping in } \\
\text { touch with } \\
\text { family }\end{array}$ & $\begin{array}{l}\text { Keeping in } \\
\text { touch with } \\
\text { friends }\end{array}$ & $\begin{array}{l}\text { To meet neu } \\
\text { people }\end{array}$ \\
\hline & & & & Count & Count & Count & Count \\
\hline \multirow{6}{*}{ GENDER } & \multirow{3}{*}{ M } & \multirow{3}{*}{$\begin{array}{l}\text { FREQ OF } \\
\text { USAGE } \\
\text { OF SNS } \\
\text { PER DAY }\end{array}$} & $1 / 2-1 \mathrm{HR}$. & 2 & 3 & 0 & 0 \\
\hline & & & 1-3 HRS. & 9 & 1 & 1 & 2 \\
\hline & & & $\begin{array}{l}\text { MORE THAN } 3 \\
\text { HRS. }\end{array}$ & 3 & 0 & 7 & 4 \\
\hline & \multirow{3}{*}{$\mathrm{F}$} & \multirow{3}{*}{$\begin{array}{l}\text { FREQ OF } \\
\text { USAGE } \\
\text { OF SNS } \\
\text { PER DAY }\end{array}$} & $1 / 2-1 \mathrm{HR}$ & 1 & 1 & 0 & 0 \\
\hline & & & 1-3 HRS. & 6 & 3 & 4 & 0 \\
\hline & & & $\begin{array}{l}\text { MORE THAN } 3 \\
\text { HRS. }\end{array}$ & 3 & 0 & 2 & 3 \\
\hline
\end{tabular}

Out of 32 males, 14 use SNS just for fun purposes among which only 2 spend $1 / 2-1 \mathrm{hr} ., 9$ spend around 1-3 hrs. and 3 spend more than 3 hrs. on SNS per day; 4 use SNS to keep in touch with family among which 3 spend $1 / 2-1 \mathrm{hr}$. and only 1 spend 1-3 hrs. on SNS per day; 8 use SNS to keep in touch with friends out of which only 1 spend 1-3 hrs. and 7 spend more than 3 hrs. on SNS per day; and 6 use SNS to meet new people out of which 2 spend 1-3 hrs. and 4 spend more than 3 hrs. on SNS per day.

Similarly, out of 23 females, 10 use SNS just for fun purposes among which only 1 spend 1/2-1 hr., 6 spend around 1-3 hrs. and 3 spend more than 3 hrs. on SNS per day; 4 use SNS to keep in touch with family among which only 1 spend $1 / 2-1 \mathrm{hr}$. and 3 spend 1-3 hrs. on SNS per day; 6 use SNS to keep in touch with friends out of which 4 spend 1-3 hrs. and 2 spend more than 3 hrs. on SNS per day; and only 3 use SNS to meet new people spending more than 3 hrs. on SNS per day.

Table-16: ANOVA

\begin{tabular}{|l|l|l|l|l|l|l|}
\hline \multicolumn{2}{|c|}{} & Sum of Squares & df & Mean Square & F & Sig. \\
\hline \multirow{3}{*}{ GENDER } & Between Groups & .362 & 2 & .181 & .724 & .490 \\
\cline { 2 - 8 } & Within Groups & 13.019 & 52 & .250 & & \\
\hline & Total & 13.382 & 54 & & & \\
\hline \multirow{3}{*}{ PURPOSE OF USING SNS } & Between Groups & 14.643 & 2 & 7.322 & 6.542 & .003 \\
\cline { 2 - 8 } & Within Groups & 58.193 & 52 & 1.119 & & \\
\cline { 2 - 8 } & Total & 72.836 & 54 & & & \\
\hline
\end{tabular}

We carried out one way ANOVA to find the significant relationship between the time spent by males and females on SNS per day and their purpose of using SNS.

In case of gender, since the significance value i.e., 0.490 is greater than the level of significance of $5 \%(0.05)$ we could not find sufficient evidences to reject the null hypothesis and hence conclude that the difference between the two attributes is insignificant.

In case of purpose of using SNS, since the significance value i.e., 0.003 is less than the level of significance of $5 \%(0.05)$ we could find sufficient evidences to reject the null hypothesis and hence conclude that the difference between the two attributes is significant.

This implies that there is no significant relationship between the gender of respondents and their frequency of using SNS per day. However, there is a significant relationship between the purpose of using SNS by respondents and their frequency of using SNS per day.

\section{ConClusion}

Majority of our sample feels that mobile phones have affected their interpersonal relationships among colleagues. However, at 5\% significance level it has been observed that there is no significant relationship between the type of mobile connection respondents possess and its effects on interpersonal relationships among colleagues.

All our respondents feel the importance and usefulness of SNS in their academic work. But however, no significant relationship between the educational qualifications of the respondents and the importance of SNS on their academic work can be proved. 
Purpose of SNS for maintaining interpersonal relationships can be seen for having more interaction, better communication and the want for keeping in touch. In the research it has been proved that there is a significant relationship between the age of respondents and their purpose of choosing SNS for maintaining interpersonal relationships.

Also, majority of the respondents use SNS as a fun-loving activity followed by using it as a source of keeping in touch with their friends and family. But at the same time, it has been tested and seen that there is no relationship between the gender of respondents and their frequency of using SNS per day. However, there is a relationship between the purpose of using SNS by respondents and their frequency of using SNS per day.

Social media has become an inevitable part of our life. As technology gets advanced, people are bound to run along with them.

\section{RECOMMENDATIONS}

Excessive use of mobile phones is bad for our eyes and even for our psychological health. Constant over-use of mobile phones leads to increased anxiety. It also creates a feeling of lonliness and lower self esteem. All this is supported by our social media. Social media presents a life which is far away from the reality. The nature of human beings leads to comparison of these false realities with their own lifes. This comparison leads to a more stressful life and a fear of faliure, a fear of missing out. Instead of sitting idle and scrolling through SNS, one should utilize this time to explore their hobby (like painting, sketching, dancing) learn something new (like a new language) or something of their interest, develop a skill, engage in mindful meditation, and the list is endless. This is something that an individual must realize himself/herself and work towards it in order to live a quality life, a life which is more about living and enjoying in the present moment instead wasting their lifes on SNS and also escaping from the reality. Parents should make it a point to ensure that their children are not always glued to the mobile screens. They must ensure that they are doing something fruitful, meaningful, that adds knowledge and value to their lives.

Mobile phones at workplace are taking a toll on the productivity of employees. Although a device-less environment at workplace might be an ideal situation, it is no longer a realistic expectation. It is better to accept that mobile phones are a part of modern-day work life and formulate policies to control their usage. Set limits on usage and even prohibit under certain situations (like during training sessions, meetings, conferences, brainstorming sessions). Minimize disruptions by keeping phones on silent mode, speaking softly, keeping calls short, avoiding offensive language, taking personal calls in private. Policy should also include the acceptable time of using mobile phones, such as during breaks or lunch time, the frequency and length of calls permitted during working hours. In order to ensure that the policy for appropriate mobile phone conduct is well understood and followed by everyone it should be put in writing. Spell out the terms in clear, unambiguous words along with the rationale of each, such as to ensure safety or maintain productivity. Include the disciplinary actions that will follow in case of violation of policy. Enforce the policy consistently and uniformly and keep a check on violators.

Flexibility in the workplace allows employers and employees to make arrangements about working conditions that suit them best. This helps employees maintain a healthy work-life balance and can help employers improve the productivity and efficiency of their business. Protocols that allow use of mobile phones during breaks should be practiced.

\section{REFERENCES}

1. Alzwamri, A.A.F., \& Hussain, N. (2017). The impact of smartphones on work productivity as perceived by employees at a government department in Salalah, Oman. Journal of Islamic Social Sciences and Humanities, 20(10), 20-24.

2. Parvez, M.S., Rahaman, M.A., Fatema, K., \& Mondal, D.R. (2019). Impact of Social Networking Sites on Interpersonal Relationship among Teenager: A Sociological Analysis in the District of Bagerhat. British J. of Arts and Humanities, 1 (5), 14-27.

3. Mittal, P. (2020). A multi-criterion decision analysis based on PCA for analyzing the digital technology skills in the effectiveness of government services. In 2020 International Conference on Decision Aid Sciences and Application (DASA) (pp. 490-494). IEEE. https://doi.org/10.1109/DASA51403.2020.9317241

4. Pitichat, T. (2013). Smartphones in the workplace: Changing organizational behavior, transforming the future. LUX: A Journal of Transdisciplinary Writing and Research from Claremont Graduate University, 3(1), 13.

5. Ferreira, A., \& Du Plessis, T. (2009). Effect of online social networking on employee productivity. South African Journal of Information Management, 11(1), 1-11.

6. Bányai, F., Zsila, Á., Király, O., Maraz, A., Elekes, Z., Griffiths, M.D. (2017). Problematic Social Media Use: Results from a Large-Scale Nationally Representative Adolescent Sample. PLoS ONE, 12(1): e0169839. 
7. HaeJung, K. (2012). The dimensionality of fashion-brand experience. Journal of Fashion Marketing and Management, 16(4), 418-441.

8. Bhowmick, T., \& Madhu, S. (2020). Social media and its influence on social skills, International Research Journal of Modernization in Engineering Technology and Science

9. Betul, K., Niall, McCrae. \& Annmarie, G. (2020). A systematic review: the influence of social media on depression, anxiety and psychological distress in adolescents, International Journal of Adolescence and Youth, 25:1, 79-93

10. Rideout, V., \& Robb, M. B. (2018). Social media, social life: Teens reveal their experiences. San Francisco, CA: Common Sense Media.

11 .

12. Alalawi, A., Kukreja, G., \& Gupta, K. (2016). Free Cash Flow as a Determinant of Performance and Stock Price Movement in Multinational Energy Companies. Journal of Business Management and Information Systems, 3(1), 11-29. https://doi.org/10.48001/jbmis.2016.0301002

13. Arora, A., Chakraborty, P., Bhatia, M. P. S., \& Mittal, P. (2020). Role of Emotion in Excessive Use of Twitter During COVID-19 Imposed Lockdown in India. Journal of Technology in Behavioral Science. https://doi.org/10.1007/s41347-020-00174-3

14. Azimee, S., \& Akhter, J. (2018). Financial Inclusion in India - Major Issues. Journal of Business Management and Information Systems, 5(1), 16-24. https://doi.org/10.48001/jbmis.2018.0501003

15. Bhatia, A., \& Mittal, P. (2019). Big Data Driven Healthcare Supply Chain: Understanding Potentials and Capabilities. SSRN Electronic Journal. https://doi.org/10.2139/ssrn.3464217

16. Blackwell, D., Leaman, C., Tramposch, R., Osborne, C., \& Liss, M. (2017). Extraversion, neuroticism, attachment style and fear of missing out as predictors of social media use and addiction. Personality and Individual Differences, 116, 69-72.

17. Chakraborty, P., Mittal, P., Gupta, M. S., Yadav, S., \& Arora, A. (2020). Opinion of students on online education during the COVID-19 pandemic. Human Behavior and Emerging Technologies, 66, 37-39. https://doi.org/10.1002/hbe2.240

18. Gupta, M. (2020). Abuse of Dominant Position by Google LLC - A Case Analysis. Journal of Business Management and Information Systems, 7(1), 11-21. https://doi.org/10.48001/jbmis.2020.0701002

19. Gupta, S. (2015). Warding off the Ponzi Trap: Eschewing the Quick Buck Promise that can Dupe You. Journal of Business Management and Information Systems, 2(2), 19-21. https://doi.org/10.48001/jbmis.2015.0202002

20. Ivanova, A., Gorbaniuk, O., Błachnio, A., Przepiórka, A., Mraka, N., Polishchuk, V., \& Gorbaniuk, J. (2020). Mobile phone addiction, phubbing, and depression among men and women: A moderated mediation analysis. Psychiatric Quarterly, 1-14.

21. Kaur, A. (2017). Does Taxation Effect FDI in India? An Empirical Study of Hartman Model. Journal of Business Management and Information Systems, 4(1), 29-42. https://doi.org/10.48001/jbmis.2017.0401004

22. Kumar, A. (2020). Disruptive Technologies and Impact on Industry- An Exploration. Journal of Business Management and Information Systems, 7(1), 1-10. https://doi.org/10.48001/jbmis.2020.0701001

23. Matthes, J., Karsay, K., Schmuck, D., \& Stevic, A. (2020). "Too much to handle": Impact of mobile social networking sites on information overload, depressive symptoms, and well-being. Computers in Human Behavior, 105, 106217.

24. Mittal, P. (2017). Time Series Analysis Using ARCH Models: A Case Analysis of Australian Stock Index. VEETHIKA-An International Interdisciplinary Research Journal, 3(1), 74-80. https://doi.org/10.48001/veethika.2017.03.01.007

25. Mittal, P. (2019). Impact of Auto-regressive (AR) Process in Bullwhip Analysis in a Multi-location Supply Chain Network. Journal of Business Management and Information Systems, 6(1), $19-26$. https://doi.org/10.48001/jbmis.2019.0601002

26. Mittal, P. (2020). Big data and analytics: a data management perspective in public administration. International Journal of Big Data Management, 1(1), 1. https://doi.org/10.1504/ijbdm.2020.10032871

27. Mittal, P. (2020). Impact of Digital Capabilities and Technology Skills on Effectiveness of Government in Public Services. In 2020 International Conference on Data Analytics for Business and Industry: Way Towards a Sustainable Economy (ICDABI) (pp. 1-5). IEEE. https://doi.org/10.1109/ICDABI51230.2020.9325647

28. Parashar, A. (2018). Factors Affecting Retirement Planning Behavior of Working Individuals: A Case Study in Lucknow. Journal of Business Management and Information Systems, 5(1), 25-34.

29. Schivinski, B., Dąbrowski, D. (2016). "The effect of social media communication on consumer perceptions of brands". Journal of Marketing Communications, 22(2): 189-214.

30. Shabnoor, S., \& Tajinder, S., "Social Media its Impact with Positive and Negative Aspects",

31. Siddiqui, T. H., \& Yadav, R. K. (2019). A Study of Marketing Strategies of Pharmaceutical Industry in India. Journal of Business Management and Information Systems, 6(1), 27-37.

32. Subramanian, K. R. (2017). Influence of social media in interpersonal communication. International Journal of Scientific Progress and Research, 38(2), 70-75. 
33. Uma, Maheswari. S., \& Vasanthanayaki. C. (2017). Performance Analysis Of Compressing Sensing Framework On Interactive Media Contentl, International Journal Of Pure And Applied Mathematics, Vol. 116, No. 11, Pp. 241 -250.

34. Varadharajulu, P., \& Meenakumari, S. (2017). The Implication of Internal Social Media on Employee Engagement in IT Companies. Journal of Business Management and Information Systems, 4(1), 43-52. https://doi.org/10.48001/jbmis.2017.0401005

35. Velga, V., "Impact of Social Media on Interpersonal Communication Patterns", Socialiniu Moksly Studijos Societal Studies, 7(1), 2015, 124-138.

36. Verma, C. P., Bansal, R., \& Mittal, P. (2020). Control of COVID-19: A Counter Factual Analysis. Administrative Development, Journal of HIPA, Shimla, 7(1), 1-24.

37. Yadav, S., Chakraborty, P., Mittal, P., \& Arora, U. (2018). Children aged 6-24 months like to watch YouTube videos but could not learn anything from them. Acta Paediatrica, 107(8), 1461-1466. https://doi.org/10.1111/apa.14291

38. Zhao, P., Yaobin, L.U., Bin, Wang., \& Patrick, Y.K., Chau. (2017). Who Do You Think You Are? Common and Differential Effects of Social Self-Identity on Social Media Usage, Journal of Management Information Systems, 34:1, 71-101

Citation: Garima Gupta (2021). Mobile Usage and its Impact on Interpersonal Relationships and Work Efficiency. South Asian Res J Bus Manag, 3(1), 23-33. 